81. From the report of the People's Commissar of Internal Affairs of Ukraine Antonov to the Cheka on the political situation of the Yekaterinoslav guberniya on his personal observations. (1998) Soviet village VChK - OGPU - NKVD. Documents and materials. in 4 volumes.Moscow: ROSSPEN, 1998.Vol. 1. 1918 - 1922.

82. From a two-week summary of the Yekaterinoslav GubChK during July 15 - August 1, 1920. (1998). Soviet village VChK - OGPU - NKVD. Documents and materials: in 4 volumes. Moscow: ROSSPEN, Vol. 1.1918 - 1922.

83. From the information summary for August $1-15,1920$. (1998). Soviet village of the Cheka - OGPU - NKVD. Documents and materials: in 4 volumes. Moscow: ROSSPEN, Vol. 1.1918 - 1922.

84. From the two-week informational summary of the secret department of the Cheka for September 15 - 30, 1920. (1998). Soviet Soviet village VChK - OGPU - NKVD. Documents and materials: in 4 volumes. Moscow: ROSSPEN, 1998. Vol.. 1918 $-1922$.

85. From the two-week informational summary of the secret department of the Cheka for September 15 - 30, 1920. (1998) Soviet Soviet village VChK - OGPU - NKVD. Documents and materials: in 4 volumes.Moscow: ROSSPEN, Vol. 1.1918 1922.

86. Report of the secret department of the Cheka on the insurrectionary movement as of November 1920. (1998). Soviet village VChK - GPU - NKVD. Documents and materials: in 4 volumes.Moscow: ROSSPEN, Vol. 1. 1918 - 1922.

87. Tenth Congress of the RCP (b). March 1921. (1963) Verbatim record. Moscow, $422 \mathrm{p}$.

88. 86. Lenin, V. (1974). Complete collection of works: in 55 volumes. Kyiv: Publishing House of Political Literature, $43,527 \mathrm{p}$

89. Lenin, V. (1973). Complete collection of works: in 55 volumes. Kyiv: Publishing House of Political Literature, 42. $608 \mathrm{p}$.

\section{С. Корновенко}

\section{ВПЛИВ СЕЛЯНСЬКОГО ФАКТОРА НА ЕКОНОМІЧНУ ПОЛІТИКУ БІЛЬШОВИКІВ В УКРАЇНСЬКОМУ СЕЛІ (1919-1921 РР.)}

Постановка проблеми. Початок ХХ ст. в історї українського націотворення позначений кардинальними зрушеннями, зумовленими Українською революччією 1917 - 1921 рр. Одним із доказів того, щзо Українська революиія 1917 - 1921 рр. носила селянський характер є те, щчо саме від того, в який спосіб та чи інша влада вирішить аграрне питання, залежало ї̈ політичне майбуття. Характер взаємин селянства з будь-якою владою багато в чому визначав конструктивну чи деструктивну спрямованість суспільно-політичноі активності селянства, яка, поряд із перебігом подій на фронтах, у кінцевому результаті й визначила фінал Української револючії. Фактично невдачі та поразки Центральної Ради, Гетьманату, Директорії УНР, Збройних сил Півдня Росї, радянської влади значною мірою були зумовлені селянським фактором.

Мета статті полягає у тому, шзоб дослідити вилив селянського фактора на еволюиію економічної політики більшовиків в украӥнському селі впродовж 1919-1921 pp.

Основні результати дослідження. У результаті проведеного дослідження обгрунтовано те, що революиійна активність селянства зумовила перегляд більшовиками доктринальних засад політики «військового комунізму», а згодом відмову від політики «військового комунізму», запровадження непу. Політика «військового комунізму» - політика «комуністичного итурму», «сочіалістичного фронту на селі», згортання товарно-грошових відносин.

Висновки. Оголосивши війну ринку, більшовики розпочали ї̈ насамперед з селянством - основним джерелом продуктивних надходжень до держави, активним суб'єктом Української революиії. Селянство на таке ставлення до себе з боку радянської влади відповідало антирадянським рухом опору. Результатом селянськобільшовицького протистояння стала втрата більшовиками влади влітку 1919 р. Такий перебіг подій став поштовхом до перегляду керівництвом РКП(б) доктринальних засад політики «військового комунізму». Однак упродовж кіния 1919 - 1920 рр. більшовики нічого не змінили у продовольчій політиці в українському селі. Радянська влада втратила прихильність навіть серед найбідніших прошарків украӥнського села. Територія Радянської Украӥни була всіяна вогнищами антибільшовищьких селянських збройних повстань. Під впливом револючійної активності селянства навесні 1921 p. у Радянській Украӥні було запроваджено нову економічну політику. Відновлення товарно-грошових відносин на селі відповідало настроям украӥнського селянства - активного суб 'екта тогочасної історії.

Ключові слова: економічна політика більшовиків, політика «військового комунізму», нова економічна політика, українське селянство, Українська револючія.

\section{УДК 94(477-22):339.16.012.32]"1953/1964"(045) DOI: 10.31651/2413-8142-2020-23-30-34}

А. Г. Морозов

доктор історичних наук, професор, завідувач кафедри археології та спеиіальних історичних дисциплін Черкаського наиіонального університету імені Богдана Хмельницького ORCID: https://orcid.org/0000-0001-5486-235X

А. В. Савченко аспірант Кременчуцького національного університету ім. М. Остроградського

\section{БАЗАРНА ТОРГІВЛЯ ЯК СКЛАДОВА МАТЕРІАЛЬНО-ЕКОНОМІЧНОГО ФУНКЦІОНУВАННЯ СЕЛЯНСЬКОГО ДВОРУ В РОКИ «ВІДЛИГИ»}

Висвітлено значення базарної торгівлі як важливого джерела доходів, які отримували українські селяни від реалізаиї̈ продукиї, вирощеноїв особистому присадибному господарстві. На основі залучених матеріалів польових досліджень проаналізовано иляхи і способи реалізаціі продукиї посередниитвом базарної торгівлі. Охарактеризовано чинники, щуо визначили активність селян у базарній торгівлі. Доведено, ше особиста підприсмливість селянства сприяла покращенню матеріально-побутового забезпечення селянських родин.

Ключові слова: «відлига», колгоспне селянство, особисте присадибне господарство, селянський двір, матеріальний добробут, базарна торгівля. 
Постановка проблеми. Особисте присадибне господарство українського селянства досить яскраво зберегло в собі віками притаманні селянину риси господаря власної землі, працелюбного, зацікавленого в результатах своєї праці. І саме це господарство в кризові моменти не лише годувало селян та давало можливість забезпечити хоча б необхідний добробут, а й досить часто ставало вагомим джерелом прибутків. Підприємницька ініціатива селян допомагала їм у реалізації власноруч вирощеної продукції як основного складника неформальної економіки селянського двору. Тому економічний потенціал та підприємницька ініціатива селян-господарів особистих присадибних господарств у роки «відлиги», пошук ними найефективніших шляхів для отримання додаткових джерел прибутків потребують детального аналізу й належного висвітлення.

Аналіз останніх досліджень і публікацій. Економічні реалії повсякденного життя сільського населення в 1953-1964 рр. з'ясовано такими українськими дослідниками, як В. Лисак [1], М. Кагальна [2], В. Кузьменко [3]. Проте, незважаючи на появу низки наукових розвідок, що стосуються прибутків української селянської родини в роки «відлиги», ролі в повсякденному житті селян торгівлі на колгоспних ринках, значення базарної торгівлі як важливого джерела прибутків ще не було предметом наукового пошуку в сучасних вітчизняних селянознавчих студіях. Для відтворення адекватної картини тогочасних подій нами було використано селянські розповіді, зібрані в результаті польових досліджень, ініційованих Науково-дослідним інститутом селянства. Спогади сучасників доби «відлиги» становлять джерельну базу нашої наукової розвідки.

Метою статті $\epsilon$ вивчення джерел наповнення родинних бюджетів українського селянства, зокрема прибутків від базарної торгівлі як складника матеріально-економічного функціонування селянського двору в роки «відлиги».

Виклад основного матеріалу. Після смерті Й. Сталіна держава дещо послабила всеосяжний економічно-фінансовий тиск на селянинаколгоспника. В перші роки свого керівництва М. Хрущов змушений був, зважаючи на необхідність перемогти у внутрішньокремлівській боротьбі, вдавати вигляд, що особисті присадибні господарства мають право на місце в житті селян-колгоспників. Тому навіть мінімальне повернення держави обличчям до селянина та вже перші кроки, спрямовані на підвищення матеріальної зацікавленості колгоспників у результатах своєї праці, швидко спрацювали. Завдяки особистій підприємливості селянства почалося покращення матеріального забезпечення селянських родин. Українські селяни активно розширили способи отримання додаткових доходів від особистого присадибного господарства. Ця практика дала відчутний результат, колгоспники доволі більше переймалися власними інтересами, власним господарством, досить часто лише імітуючи, а й іноді просто відверто ігноруючи працю в колективному господарстві $[4,476]$.
Серед джерел доходів, які отримували українські селяни від реалізації продукції, вирощеної в особистому присадибному господарстві, на чільному місці був її продаж на ринках, які офіційно в СРСР називали «колгоспними ринками» (серед населення побутувала й інша назва - «базари», «базарна торгівля») [3, 111]. Активізації саме такого шляху реалізації власної продукції сприяли і окремі законодавчо-нормативні акти, прийняті державою в контексті нового курсу аграрної політики, ініційованого М. Хрущовим. Так, 30 жовтня 1953 р. Радою Міністрів УРСР було прийнято постанову «Про заходи по поліпшенню колгоспної торгівлі на ринках УРСР». Документом визначалася конкретна мета: впровадити низку заходів задля покращення постачання населення міст і промислових центрів сільськогосподарськими продуктами [5, 315]. Зміст постанови розширював можливості українського селянства у сфері реалізації сільськогосподарської продукції, вирощеної в особистому присадибному господарстві. Однак більшість представників радянсько-партійного керівництва не вважала таке отримання прибутків елементом соціалістичного укладу економіки.

Радянські дослідники хрущовського періоду, розглядаючи соціально-економічну природу торгівлі на колгоспних ринках, ідеологічно заангажовано і досить критично говорили про отримання прибутків не від колгоспного виробництва. Звичайно, вони не могли повністю відкидати її значення для піднесення матеріального добробуту саме виробників сільськогосподарської продукції. Однак досить часто вони трактували торгівлю на колгоспних ринках як таку, що відбирає час і можливість селян краще проявити себе в колективному господарстві, оскільки в особистих присадибних господарствах щороку було зайнято до 10 млн. осіб, а на колгоспних ринках України щоденно торгувало «в середньому 225-245 тисяч осіб, а по неділях до півмільйона осіб» $[6,26]$.

$\mathrm{У}$ повоєнний час, коли продовольча проблема стояла досить гостро і потребувала нагального ii вирішення, колгоспні ринки були вагомим джерелом наповнення міст продуктами харчування. Вони офіційно були організовані й активно функціонували в селах, селищах, містечках, містах, при залізничних станціях. Мережа колгоспних ринків характеризувалася динамікою росту: як офіційно дозволених ринків, так і стихійних. Останні найчастіше виникали спонтанно і розташовувались в основному в містах просто на пішохідних тротуарах, на міських площах, біля залізничних вокзалів, часто просто поруч з ринками офіційними [3, 113].

На стихійних ринках, наприклад, біля залізничних вокзалів, торгівля пожвавлювалася в години прибугтя потягів дальнього та приміського сполучення. В основному така стихійність була характерна для невеличких залізничних вокзалів, про що свідчать й матеріали польових досліджень. В основному респонденти, які згадували про торгівлю на ринках біля залізничних станцій, називали саме такі незначні за обсягом пасажироперевезень і зупинок потягів вокзали. Жителі навколишніх сіл знали розклади руху 
потягів, тому й старалися вивозити свою продукцію, підлаштовуючись під години їх прибуття.

Іноді стихійні ринки створювалися просто на трасах. Найчастіше це відбувалось у тих випадках, коли населений пункт був розташований на зручних для торгівлі магістралях. Продукція іноді просто виставлялась біля дороги поруч із будинком. Асортимент залежав від сезонності сільськогосподарської продукції, від спеціалізації селянського двору тощо. Популярність таких стихійних ринків на трасах визначалася низкою чинників, серед яких досить вагомим було те, що селяни в більшості випадків не мали власного транспорту, щоб доставити продукцію на офіційні ринки, тому й влаштовували стихійну торгівлю поряд із власним помешканням.

Для відтворення адекватної картини чисельних динамічних змін у соціально-економічному житті тогочасного українського села наукову цінність мають матеріали, отримані як свідчення безпосередніх сучасників тих подій, суб'єктів життя українського села доби «відлиги». Опрацьовані нами матеріали польових досліджень Науково-дослідного інституту селянства містять значну кількість розповідей, зібраних у результаті бесід із селянами з різних регіонів України. Матеріали, зібрані під час польових досліджень вже в умовах незалежної демократичної України, свідчать про те, що масовою тенденцією серед селянства була реалізація сільськогосподарської продукції шляхом базарної торгівлі.

«Кому щастило, то в місто подалися. А ми в селі своїми руками на хліб заробляли. Кожних вихідних на базарі торгували»; «...хотілось копійку заробити якусь, щоб голодними не бути», - часто зазначали в спогадах колишні колгоспники. «Працювали важко, а грошей отримували мінімально. Звісно ж займались домашнім господарством. Біля хати мали свою норму землі в 60 соток (0,6 га). Вирощували баштан, кукурудзу, картоплю, буряк, горох. Був невеличкий садок i виноградник. Садову продукцію везли на базар, i трохи залишали собі, спускали в погріб. Тримали качок, гусей та індиків. М'яса птиці зазвичай вистачало лише, щоб прогодувати велику сім'ю. Але іноді все ж таки відвозили в Знам' янку на ринок. Праця тяжка була, але приходилось працювати», - розповідала дослідникам А.П. Корнієнко, мешканка с. Іванківці Знам'янського району Кіровоградської області [7, арк. 1].

Значна кількість селянських розповідей містить інформацію про те, чим саме торгували на ринках. Загалом, як часто зазначали селяни, «вирощували все, що росло. I продавали також все, що можна було продати». Переважали продукти тваринництва. Селяни продавали як живу худобу, вирощену в особистому присадибному господарстві, так і м'ясо, яйця, молоко, сметану, сир, ряжанку тощо. Особисті господарства, в яких була корова, часто називали їі «годувальницею» і віддавали багато сил, щоб надої молока від власної корови були значними. Колишня доярка С.В.Базевлюк з с. Руська Поляна Черкаського району Черкаської області згадувала: «Видоїмо корів, нагодуємо, приберемо, відра і бідони помиємо і живенько додому біжимо поратися. Тоді вже ближче до вечора знову до роботи. І так кожного дня. Вдома також худоба була - корівка Зорька, ох і молока давала багато. Сиру й сметани зроблю та й біжу в суботу в центр села продавати» [8, арк. 1]. Селянські господарства, в яких розводили кіз, мали стабільний додатковий дохід від продажу козиного молока на місцевому ринку.

Розповсюдженим було вирощування і подальша реалізація домашньої птиці (в основному курей, качок, гусей). Досить часто кількість птиці в особистому присадибному господарстві становила 100 одиниць. Найчастіше птицю різали в листопаді, вивозили на базари до районних центрів. На зароблені гроші на цьому ж ринку купляли речі та новий одяг. Якщо торгівля була вдалою, то ще й залишались гроші для інших нагальних потреб.

Чільне місце в продукції, яка 3 особистого присадибного господарства реалізовувалася на колгоспних ринках, традиційно займала городина (огірки, часник, цибуля, редька, картопля, капуста, квасоля тощо), плоди фруктових дерев, насіння, ягоди, горіхи, продукти бджільництва. Також вирощували зернові культури, мололи і продавали борошно. Окрім того, власники особистих присадибних господарств, в яких були виноградники, реалізовували на базарі ягоди винограду різних сортів, саджанці виноградної лози, домашнє вино. Серед матеріалів інтерв'ю 3 селянами є й згадки про те, що, якщо особисте господарство було недалеко коло лісу, то найчастіше в сезон селяни торгували лісовими ягодами та грибами. Респонденти в своїх спогадах іноді акцентували увагу на тому, що скрутне матеріальне становище інколи спонукало селян до не зовсім законних дій. Зокрема, вони розповідали, що сільські мешканці вирощували тютюн, який потім різали та продавали на базарі на «стаканчик».

Серед записів, зібраних в результаті польових досліджень, $є$ й свідчення відносно того, що в сезонність певних сільськогосподарських продуктів (найчастіше це були овочі та фрукти) колгоспники навіть пропускали трудодні, продавали продукцію на місцевих базарах, а пізніше трудодні відпрацьовували.

Помітною тенденцією 1950-х-1960-х рр. була реалізація селянами сільськогосподарської продукції з особистого присадибного господарства за межами власного регіону з метою отримання максимального прибутку. Селяни виїздили на базари в великі міста та промислові центри як України (Київ, Одеса, Донецьк тощо), так і за межі республіки. Продавши на ринку сільськогосподарську продукцію, за яку отримували значно більші кошти, чим від торгівлі на місцевих ринках, селяни закупляли дефіцитні товари, яких не було ні в їхній сільській місцевості, ні в районних (та й навіть в обласних) центрах. Для мешканців сіл, яких держава свідомо обмежувала в забезпеченні споживчих потреб, дефіцитом було майже все. На початку 1960-х рр. характерною ознакою стає зменшення у роздрібному товарообігу частки навіть традиційних для сільських крамниць товарів: солі, тютюну, алкоголю, сірників, гасу [9, 121]. Проте, якщо деякі товари (ковбасні та кондитерські вироби, цукор, сіль, сірники, тканини, засоби гігієни) можна було придбати і в районних та обласних центрах, то велосипеди, мотоцикли, побутову техніку (праски, швейні машинки. радіоприймачі), столярні 
інструменти вони могли придбати лише в великих містах, промислових центрах $[10,133]$. За згадками старожилів, із далеких поїздок вони також привозили й дефіцитні тканини. В основному це була вовняна тканина «бастон» на пальто, шовк на випускні та весільні сукні. Як часто зазначалось в розповідях селян, то «грошей на дрібниці вони не тратили, так як їх мало вистачити до нового врожаю» [11, 622].

Часто продукцію возили на південь республіки. Селяни пригадували: «...батьки та й всі жителі села старались частіше возити картоплю на південь, на продаж, тому що в той час врожаю там не було; возили також огірки, цибулю, іншу сільськогосподарську продукцію. Батьки вирощували багато городини і також скуповували продукцію в сусідів, тому що не кожен мав можливість поїхати в таку даль: брак коштів, доріг та транспорту. Дізнавались, в яких районах немає певної сільськогосподарської продукції та де які ціни, туди і їхали» [12, арк. 2]. На Донбас також часто вивозили городину і обмінювали їі там на місцевих ринках на продукти, які вдома були дефіцитом. На продаж вивозили також м'ясо худоби та домашньої птиці (одним із найпоширеніших маршрутів були поїздки до м. Київ). Відсутність сучасних технологій транспортування на далекі відстані продукції, яка швидко псується, компенсувалася кмітливістю селян. Для транспортування м'яса на віддалені відстані взимку селяни вирубували кригу на ставку, обкладали нею м'ясо і возили на базар продавати [13, арк.1].

Вигідні умови для продажу сільськогосподарської продукції визначали й досить віддалені маршрути, які сягали далеко за межі республіки. Найбільшою привабливістю i, відповідно, популярністю користувалась столиця Радянського Союзу м. Москва, проте продукцію возили і в Білорусію, і в інші російські міста, зокрема, на Північ. Спогади респондентів, які брали участь у польових дослідженнях, наповнені інформацією, що селяни вивозили на реалізацію продукцію довготривалого зберігання (сухофрукти, чорнослив, насіння, сушену рибу тощо). Далекі поїздки селяни здійснювали переважно в час, коли активні польові роботи були завершені. Вагомим чинником було те, що селяни залишались «прив'язаними» до колгоспів, і в зимовий час можливість отримати дозвіл в керівництва колгоспу на поїздку була більш реальною, чим в інші пори року.

Позитивними моментами таких далеких поїздок було те, що селяни отримували за свою продукцію значно більший прибуток, чим від іiї реалізації на місцях. До негативу маємо віднести те, що популярність серед сільського населення вивезення продукції за межі регіону зменшувало обсяги реалізованої продукції на місцях. Тому держава різними способами намагалась обмежувати цей шлях реалізації сільськогосподарської продукції. «Їздили потайки, переховувались та досить складним шляхом добирались до місця призначення», - зазначали безпосередні учасники тих подій.

Висновки. Підприємницька ініціатива селянства давала йому можливість отримувати додаткові доходи шляхом реалізації сільськогосподарської продукції, вирощеної в особистому присадибному господарстві, посередництвом саме базарної торгівлі. Радянська система через низку об' єктивних чинників все ж змушена була дозволити базарну торгівлю, хоч і вважала ії капіталістичним пережитком, якому немає місця в соціалістичному ладі. Проте саме торгівля на ринках була для колгоспників та їх родин суттєвим джерелом наповнення бюджету.

\section{Список використаної літератури та джерел:}

1. Лисак В. Особисте присадибне господарство в сукупному прибутку української селянської родини в 1950-1960-х роках. Гілея. 2009 Вип. 20. С 105-107.

2. Кагальна М. Матеріальне забезпечення селянства УРСР у період хрущовської «відлиги» крізь призму повсякдення (1953-1964рр.). Архіви України. 2013. № 2. C. 70-78.

3. Кузьменко В. Торгівля на колгоспному ринку в повсякденному житті сільських жителів УРСР в 1940-1960х роках (за матеріалами Чернігівської області). Етнічна історія народів Європи. 2016. Вип. 49. С. 111-119.

4. Скворцова I. Особисті підсобні господарства у Вінницькій і Хмельницькій областях на завершальному етапі радянської доби (60-80-ті рр.). Вісник Кам'янеиьПодільського національного університету імені Івана Огієнка. Історичні науки. 2014. Вип. 7. С. 474-483.

5. Україна: Хроніка ХХ ст.: Роки 1946 - 1960: у 2 ч. / редкол.: В.А. Смолій та ін. Київ : Ін-т історії України НАН України, 2005. Ч. 2: 1953-1960. С. 287-613.

6. Лінійчук Я. Важливе джерело піднесення народного добробуту. Київ : Видавництво політичної літератури України, 1967. 169 с.

7. Спогади Корнієнко Антоніни Петрівни, 1938 р. н., мешканки с. Іванківці Знам'янського району Кіровоградської області. Поточний архів Науководослідного інституту селянства. Ф. 1 . Матеріали польових досліджень. Справа 341/993. - 1 арк.

8. Поточний архів Науково-дослідного інституту селянства. - Ф.1. Матеріали польових досліджень. - Справа 341/979. Спогади Базевлюк Світлани Володимирівни, 1943 р.н., мешканки с. Руська Поляна Черкаського району Черкаської області. 1 арк.

9. Клок В. Розвиток споживчої кооперації України в умовах десталінізації (1956-1965 роки). Вісник Львівської комериійної академії. Серія: Гуманітарні науки. 2013. Вип. 11. C. $117-127$.

10. Кузьменко В. Дефіцит в повсякденних практиках сільських жителів УРСР в 1950-1960-х роках (за матеріалами Чернігівської області). Етнічна історія народів Свропи. 2017. Вип. 53. С. 130-134.

11. Соціальні трансформації в Україні: пізній сталінізм i хрущовська доба. Київ : Інститут історії України, 2014. $697 \mathrm{c}$.

12. Поточний архів Науково-дослідного інституту селянства. Ф. 1. Матеріали польових досліджень. Справа 342/024. Спогади Ковилова Володимира Івановича та Ковилової Ольги Василівни, мешканців с. Рижівка Уманського району Черкаської області. 2 арк.

13. Поточний архів Науково-дослідного інституту селянства. Ф. 1. Матеріали польових досліджень. Справа 342/004. Спогади Санжарівського Олександра Григоровича, мешканця с. Ташлик Смілянського району Черкаської області. 1 арк.

\section{References:}

1. Lysak, V. (2009). Personal homestead in the total income of the Ukrainian peasant family in the 1950-1960's. Gilea, 20, 105-107. (in Ukr).

2. Kagalna, M. (2013). Material support of the peasantry of the USSR in the period of Khrushchev's "thaw" through the prism of everyday life (1953-1964). Archives of Ukraine, 2, 70-78. (in Ukr).

3. Kuzmenko, V. (2016). Trade in the collective farm market in the daily life of rural residents of the USSR in 1940-1960 (according to the Chernihiv region). Ethnic history of the peoples 
of Europe, 49, 111-119. (in Ukr).

4. Skvortsova, I. (2014). Personal farms in Vinnytsia and Khmelnytsky regions at the final stage of the Soviet era (6080's). Bulletin of Ivan Ogienko National University of Kamyanets-Podilsky. Historical sciences, 7, 474-483. (in Ukr). 5. Ukraine: Chronicle of the twentieth century : Years 1946 1960: 2 hours. (2005). (Ed) V. A Smoliy. Kyiv: Institute of History of Ukraine, National Academy of Sciences of Ukraine, Part 2: 1953-1960, 287-613. (in Ukr).

6. Liniychuk, J. (1967). An important source of raising the welfare of the people. Kyiv: Publishing House of Political Literature of Ukraine, 1967. 169 p. (in Ukr).

7. Memoirs of Antonina Petrovna Kornienko, born in 1938 , resident of the village of Ivankivtsi, Znamyansky district, Kirovohrad region. Current archive of the Peasant Research Institute. F. 1. Materials of field research. Case 341/993. - 1 sheet. (in Ukr).

8. The current archive of the Research Institute of Peasants $\Phi .1$. Materials of field researches. Case 341/979. Memoirs of Svitlana Volodymyrivna Bazevlyuk, born in 1943, resident of the village of Ruska Polyana, Cherkasy district, Cherkasy region. 1 sheet.

9. Klok, V. (2013). Development of consumer cooperation in Ukraine in the conditions of de-Stalinization (1956-1965). Bulletin of the Lviv Commercial Academy. Series: Humanities, 11, 117-127. (in Ukr).

10. Kuzmenko, V. (2017). Deficit in the daily practices of rura residents of the USSR in 1950-1960 (according to the Chernihiv region). Ethnic history of the peoples of Europe, 53, 130-134. (in Ukr).

11. Social transformations in Ukraine: late Stalinism and Khrushchev's era. (2014). Kyiv: Institute of History of Ukraine. (in Ukr).

12. Current archive of the Research Institute of Peasants. F. 1 Materials of field research. Case 342/024. Memoirs of Kovyloy Volodymyr Ivanovych and Kovylova Olga Vasylivna, residents of the village of Ryzhivka, Uman district, Cherkasy region. 2 sheets. (in Ukr).

13. Surrent archive of the Research Institute of Peasants. F. 1 Materials of field research. Case 342/004. Memoirs of Oleksandr Hryhorovych Sanzharivsky, a resident of the village of Tashlyk of Smilyansky district of Cherkasy region. 1 sheet. (in Ukr).

\section{A. Morozov, A. Savchenko}

\section{THE BAZAAR TRADE AS A COMPONENT OF MATERIAL AND ECONOMIC FUNCTIONING OF THE PEASANTS' HOUSEHOLD DURING THE YEARS OF KHRUSCHOV'S «THAW»}

Introduction The article deals with the importance of trade marketplace as an important source of income that Ukrainian farmers received from the sale of products grown in their personal private households. Based on materials of field researches the ways and means of sales through trading marketplaces are analized Attention is paid to the characteristics of the factors that determined the activity of peasants in the market trade. It is proved that the personal entrepreneurship of the peasantry contributed to the improvement of the welfare of peasant famr Eilies.

Purpose. Tre purpose of research is to study the sources of Ukrainian peasant families' budgets, that is their profits from market traide as the part of material and economical functioning of a peasant household in the period of Khruschov" "thaw" (1953 - 1964).

Results. After the death of J. Stalin the state had weakened total economic financial press on the peasant - collective farmer. Due to the private enterprising of peasants there appeared improvement of theirfamilies' material maintenance. Ukrainian peasants began to expand actively the ways of getting extra profits from their private plots of land. Such an activity gave an appreciable result. The collective farmers started more and more take care of their own interests, their own household. Since then they often pretended or even ignored the work in the collective farm.

Among the sources of profits which Ukrainian peasants got from realizing of products grown on their private households the sail them in the markets was the most important. In the USSR they were called collective farms' markets (they had another name among the population - bazaars. Some lawnormative acts adopted by the state in the context of the new course of the agrarian policy, initiated by Khruschev, favoured the activation just such a way of realization of peasant products.

The notable tendency of 1950-1960-ies was the realization of products from the private household beyond the borders of their own region with the aim of getting maximum profit. Peasants went to bazaars in big cities and industrial centers of Ukraine (Kyiv, Odessa, Donetsk, etc.) as well as of other Union republics. Having got more money for their agricultural products then they could get on their local markets, the peasants bought commodities in short the lack of which was in their rural location as well as in district and even in regional centers.

Profitable conditions for selling agricultural products determined rather remote routs that spared much farther than the borders of the republic. Most attractive and, accordingly, popular was the capital of the Soviet Union - Moscow though the production was brought to Belarus, other Russian cities, especially to the North, as well. Respondents' memouirs who took part in the field researches are full of the information about the fact that peasants transported production of long-term storage (dried fruit, prunes, walnuts, sunflower seeds, dried fish, etc.). The peasants preferred to make theirfar travels in times when active field works have been finished. The important factor was they had been attached to their collective farms, and to get the authority permittance for travel in winter time was much more real than in any other season.

Conclusion. Peasants' business initiation gave them the possibility to get extra income realizing agricultural production that they had grown in their own households by means of bazaar trade. Through the number of the objective facts, the Soviet system was forced yet to permit the bazar trade though it considered it as the survival of capitalism that had no place in the socialist society. But just the bazar trade was the essential source of filling budgets for collective farmers and their families.

Key words: the period of «thaw», collective farmers, personal household, material welfare, bazaar trade, peasant families' budgets. 